\title{
MODEL TOLERANSI PADA PEMBELAJARAN SAINS KELAS VIII SEMESTER II DI SMP PESANTREN PRAMUKA ALHIRA PADANG PANJANG
}

\author{
Elsa Rahmayani Sari ${ }^{1, \square}$, M. Haviz ${ }^{1}$, Afwadi $^{2}$ \\ ${ }^{1}$ Jurusan Pendidikan (Tadris) Biologi Fakultas Tarbiyah dan Ilmu Keguruan IAIN Batusangkar \\ ${ }^{2}$ Jurusan Sosiologi Agama Fakultas Ushuluddin Adab dan Dakwah IAIN Batusangkar \\ Korespondensi: Jl. Sudirman No. 137, Kubu Rajo, Lima Kaum, Batusangkar, \\ 27213, Sumatera Barat, Indonesia. Tel.(0752)71150. Fax. (0752)71879 \\ E-mail: okeymaya@yahoo.com
}

\begin{abstract}
ABSTRAK
Penelitian ini bertujuan untuk mengetahui materi apa saja yang memiliki nilai-nilai toleransi, mendeskripsikan proses penanaman nilai-nilai toleransi dan faktor pendukung, penghambat penanaman nilai-nilai toleransi pada pembelajaran sains kelas VIII semester II di SMP Pesantren Pramuka Alhira Padang Panjang. Hasil penelitian yang dilakukan diketahui bahwa semua materi sains memiliki potensi konflik dan memiliki nilai-nilai toleransi. Materi yang memiliki tingkat kerawanan tinggi untuk terjadi konflik adalah materi sistem peredaran darah manusia karena berhubungan dengan manusia dan kehidupan sehari-hari yang berkaitan dengan pribadi siswa. Penanaman nilai-nilai toleransi dilakukan dengan menciptakan iklim toleran pada setiap pembelajaran sains serta memelihara sikap saling pengertian, saling menghargai dan saling menghormati. Beberapa faktor pendukung dan penghambat penanaman nilai-nilai toleransi tersebut adalah, faktor pendukung diantaranya: Kebijakan peraturan pemerintah, kemampuan guru dalam internalisasi nilai toleransi, dan kegiatan-kegiatan pendukung dari pihak sekolah yang berperan penting dalam proses penanaman nilai toleransi seperti kegiatan keagamaan, kegiatan kepramukaan dan kegiatan sosial. Adapaun faktor penghambat diantaranya: Tingkat kemampuan, kematangan emosional siswa yang tidak sama, kurangnya fasilitas pada ruangan laboratorium pada saat praktikum yang dapat menunjang penanaman nilai-nilai toleransi. Jadi dapat disimpulkan penelitian ini telah dapat mengungkap model toleransi pada pembelajaran sains kelas VIII semester II di SMP Pesantren Pramuka Alhira.
\end{abstract}

\section{Kata kunci: toleransi, pembelajaran sains, kelas VIII.}

\section{Pendahuluan}

Pluralitas di Indonesia akan menimbulkan nilai-nilai partikula-ristik (nilai kekhasan). Untuk men-jaga keutuhan bangsa, maka nilai partikularistik tersebut harus dimini-malisir, dengan cara menumbuhkan nilai-nilai universal atau pemikiran dan sikap bertoleransi. Upaya strate-gis dalam menumbuhkan kesepa-haman, toleransi dan saling pengertian adalah melalui pen-didikan. Pendidikan yang berpihak pada keanekaragaman dan meng-akomodasi perbedaan untuk men-capai tujuan yang sama. 
Sekolah merupakan suatu sis-tem sosial masyarakat, dimana para siswa saling belajar untuk berinter-aksi, belajar bekerjasama, belajar menghargai, dan belajar berbagai aspek kehidupan sebagaimana layak-nya dalam masyarakat. Proses belajar yang dilakukan terhadap berbagai aspek kehidupan dalam lingkungan sekolah ini akan menjadi bekal bagi siswa untuk lebih siap memasuki lingkungan masyarakat, (seperti ber-gaul, saling berkomunikasi, serta saling memberi dan saling menerima), terutama sekali setelah menamatkan pendidikan. (Endang, 2011: 94)

Sekolah memegang peranan penting dalam menanamkan nilai multikultur pada siswa sejak dini. Bila sejak awal mereka telah me-miliki nilai-nilai kebersamaan, tole-ran, cinta damai, dan menghargai perbedaan, maka nilai tersebut akan tercermin pada tingkah laku mereka sehari-hari karena terbentuk pada kepribadiannya. Bila hal ini berhasil dimiliki para generasi muda kita, maka kehidupan mendatang dapat diprediksi relatif damai dan peng-hargaan antara sesama dapat ter-wujud. (Arifudin, 2007: 2).

Menurut Rustaman (1997: 6) tujuan pembelajaran sains (IPA) selain untuk memahami konsep-konsep sains (IPA) dan keter-kaitannya, juga ditujukan untuk:

1. Meningkatkan kesadaran akan kelestarian lingkungan, ke-banggaan nasional, dan ke-besaran serta kekuasaan Tuhan Yang Maha Esa;

2. Mengembangkan daya penalar-an untuk memecahkan masalah sehari-hari;

3. Mengembangkan keterampilan proses untuk memperoleh konsep-konsep IPA dan menumbuhkan nilai serta sikap ilmiah;

4. Menerapkan konsep dan prin-sip sains (IPA) untuk meng-hasilkan karya teknologi seder-hana yang berkaitan dengan kebutuhan manusia.

Pembelajaran sains seyogiya-nya lebih menekankan pada proses, siswa aktif selama pembelajaran untuk membangun pengetahuannya melalui serangkaian kegiatan agar pembelajaran menjadi bermakna bagi siswa. Dalam pembelajaran sains, siswa berperan seolaholah sebagai ilmuan, menggunakan metode ilmiah untuk mencari jawaban terhadap suatu permasalahan yang sedang dipelajari.

Menurut Kementrian Pendi-dikan dan Kebudayaan (2014: 20) tujuan pendidikan jenjang pen-didikan dasar dan menengah, juga dinyatakan dalam peraturan pemerin-tah Nomor 17 Tahun 2010 tentang pengelolaan dan penyelenggaraan pendidikan bertujuan membangun landasan bagi berkembangnya poten-si peserta didik agar menjadi ma-nusia yang:

a. Beriman dan bertakwa kepada Tuhan Yang Maha Esa, ber-akhlak mulia, dan berkepri-badian luhur;

b. Berilmu, cakap, kritis, kreatif, dan inovatif;

c. Sehat, mandiri, dan percaya diri; dan

d. Toleran, peka sosial, demo-kratis, dan bertanggung jawab.

Menurut Kemendikbud (2014: 71) toleransi adalah sikap dan tindakan yang menghargai kebe-ragaman latar belakang, pandangan, dan keyakinan.

Contoh indikator dari sikap toleransi (Kemendikbud, 2014: 71) adalah:

1. Tidak menganggu teman yang berbeda pendapat. 
2. Menerima kesepakatan meski-pun berbeda dengan pendapat-nya.

3. Dapat menerima kekurangan orang lain.

4. Dapat memaafkan kesalahan orang lain.

5. Mampu dan mau bekerjasama dengan siapa pun yang memili-ki keberagaman latar belakang, pandangan dan keyakinan.

6. Tidak memaksakan pendapat atau keyakinan diri pada orang lain.

7. Kesediaan untuk belajar dari (terbuka terhadap) keyakinan dan gagasan orang lain agar dapat memahami orang lain lebih baik.

8. Terbuka terhadap atau ke-sediaan untuk menerima se-suatu yang baru.

Tahap awal yang perlu segera dilakukan adalah penyadaran melalui sosialisasi yang dapat dimulai pada level sekolah, untuk bisa saling mengenal dan memahami keaneka-ragaman budaya, sehingga menum-buhkan sikap saling menghargai identitas etnik yang sama maupun berbeda.

Sekolah Menengah Pertama (SMP) Pesantren Pramuka Alhira Padang Panjang memiliki siswa yang beragam atau majemuk yang berasal dari latar belakang suku, bahasa, budaya, ekonomi, latar belakang keluarga dan tingkat kecerdasan yang berbeda-beda yang berada pada satu kelas. Dengan banyaknya perbedaan yang terdapat pada Sekolah Menengah Pertama (SMP) Pesantren Pramuka Alhira Padang Panjang peneliti tertarik untuk:

1. Mengetahui bagaimana proses penanaman nilai-nilai toleransi dan

2. Model toleransi yang diajarkan di Sekolah Menengah Pertama (SMP) Alhira.

\section{Metode Penelitian}

Jenis penelitian yang peneliti lakukan adalah penelitian lapangan (Field Research) menggunakan metode deskriptif dengan pendekatan kualitatif. Penelitian ini akan mengungkapkan apa adanya mengenai model toleransi dalam pembelajaran sains.

Penelitian ini dilaksanakan pada kelas VIII SMP Semester II tahun ajaran 2015 di Pesantren Pramuka Alhira Padang Panjang yang beralamat di jalan raya Padang PanjangBukittinggi, Aie Angek Kecamatan X Koto, Kabupaten Tanah Datar. Sumber informasi adalah para informan yang ber-kompeten dan mempunyai relevansi dengan penelitian. Sesuai dengan pendekatan yang digunakan, maka instrumen yang dipakai untuk menggumpulkan data adalah peneliti sendiri.

Teknik pengumpulan data yang digunakan adalah observasi, wawan-cara, studi dokumentasi. Observasi, wawancara, studi dokumentasi untuk menganalisis model toleransi dalam proses pembelajaran sains. Teknik analisis data yang dilakukan dengan mengikuti langkah-langkah pene-litian yang dikembangkan oleh Miles dan Huberman. Ketiga kegiatan ini adalah pengumpulan data, penyajian data dan penarikan kesimpulan atau verifikasi. (Sugiyono, 2012: 60)

Teknik menjamin keabsahan data yang digunakan adalah teknik triangulasi. Triangulasi adalah teknik pemeriksaan data yang meng-gabungkan dari berbagai teknik pengumpulan data dan sumber data yang telah ada. Melalui triangulasi peneliti dapat melakukan pengecekan temuannya dengan jalan memban-dingkan dengan berbagai sumber, metode dan teori.

\section{Hasil dan Pembahasan}




\section{Analisis Proses Penanaman Nilai-Nilai Toleransi pada Pem-belajaran Sains di SMP Pesan- tren Pramuka Alhira Padang Panjang}

Dalam kaitannya dengan proses pembelajaran sains, hal penting yang harus diterapkan dalam penanaman nilai-nilai toleransi pada pembela-jaran sains di SMP Pesantren Pra-muka Alhira Padang Panjang adalah sebagai berikut:

\section{a. Kemampuan Guru dalam Pem-belajaran Sains}

Peran guru di lingkungan se-kolah dituntut menjalankan enam peran (Zubaedi, 2012: 165):

1) Harus terlibat dalam proses pembelajaran, yaitu melakukan interaksi dengan siswa dalam mendiskusikan materi pem-belajaran;

2) Harus menjadi contoh teladan kepada siswanya dalam ber-prilaku dan bercakap;

3) Harus mampu mendorong sis-wa aktif dalam pembelajaran melalui pengguanaan metode pembelajaran yang variatif;

4) Harus mampu mendorong dan membuat perubahan sehingga kepribadian, kemampuan dan keinginan guru dapat mencipta-kan hubungan yang saling menghormati dan bersahabat dengan siswanya;

5) Harus mampu membantu dan mengembangkan emosi dan kepekaan sosial siswa agar siswa menjadi lebih bertakwa, menghargai ciptaan lain, men-gembangkan keindahan dan belajar soft skills yang berguna bagi kehidupan siswa selanjut-nya;

6) Harus menunjukkan rasa kecintaan kepada siswa se-hingga guru dalam mem-bimbing yang sulit tidak putus asa.

Peranan kemampuan guru di SMP Pesantren Pramuka Alhira da-lam mengajar sains sangat baik, ini diketahui dari hasil wawancara pene-liti dengan enam orang siswa kelas VIII SMP Pesantren Pramuka Alhira, yang terdiri dari tiga orang siswa dan tiga orang siswi peneliti mendapat-kan informasi bahwa guru sains mudah senyum, ramah, tegas dan dalam menjelaskan materi sains dengan suara yang lantang dan sangat jelas, serta guru sains sangat paham dengan materi sains yang diajarkan.

\section{b. Materi Terkait}

Karakteristik materi sistem peredaran darah pada manusia:

1) Fakta:

a) Organ dan jaringan yang menyusun sistem peredaran darah manusia adalah jan-tung, pembuluh darah dan darah.

b) Alat peredaran darah terdiri atas jantung dan pembuluh darah.

c) Darah terdiri atas plasma darah, sel-sel darah, dan keping darah.

d) Penyakit yang berhubungan dengan sistem peredaran da-rah ada yang bersifat ketu-runan dan ada yang tidak bersifat keturunan.

e) Penyakit pada sistem pere-daran darah berasal dari adanya gangguan atau keru-sakan pada darah atau alat-alat peredaran darah

2) Konsep: Darah, Plasma da-rah, Sel darah merah (erit-rosit), Sel darah putih (leu-kosit), Keping darah (trom-bosit), Serum darah, Agluti-nogen, Aglutinin, Pembuluh nadi (arteri), Pembuluh balik (vena), Pembuluh aorta, Pem-buluh kapiler, Arteria koro-naria, Atrium, Ventrikel, Sis-tole, Diastole, Kontraksi, Re-laksasi, Hemofili, Anemia, Leukimia, Varises, Ambeien.

3) Prinsip :-

4) Prosedur:

a) Proses pembekuan darah 
b) Peredaran darah kecil

c) Peredaran darah besar

lmu Pengetahuan Alam (sains) mengandung banyak sekali nilai kehidupan. Nilai moral yang dapat dikembangkan dalam hal ini menya-ngkut nilai kejujuran, rasa ingin tahu, serta keterbukaan. Proses sains dalam hal ini merupakan proses mempelajari serta mengambil makna pada kehidupan dan dunia di seke-liling kita.

Menurut Prudente dan Aguja (2003), seorang guru biologi dapat merasa telah mengajarkan nilai-nilai sains biologi pada saat siswa telah dapat mengimplementasikan nilai-nilai tersebut tidak hanya di dalam kelas, akan tetapi juga dalam kehidupan nyata.

Contoh nilai religius yang dapat dikembangkan dari pem-belajaran konsep biologi yaitu sistem peredaran darah pada manusia menurut Depriya \& Wulan (2002: 14-15) antara lain: Arsitektur struk-tur arteri dan vena disesuaikan dengan fungsinya. Arteri berdinding tebal karena harus memompa darah dari jantung ke seluruh tubuh. Dengan demikian, agar dinding arteri tidak jebol (pecah) karena tekanan yang tinggi maka dindingnya harus tebal dan kuat. Vena berdinding tipis dan mempunyai katup berfungsi mengalirkan darah menuju ke jantung. Pembuluh ini berdinding tipis karena hanya memerlukan tekanan untuk membawa darah ke jantung. Pembuluh vena dilengkapi dengan katup untuk menjaga agar darah tidak mengalir mundur. Struktur kedua pembuluh darah yang sempurna sesuai dengan fungsinya ini menunjukkan tanda-tanda kebesaran Allah serta Maha kayaNya ilmu Allah dalam mengatur suatu kesatuan organ yang berfungsi dengan baik.

Berkenaan dengan hal tersebut, Allah swt., berfirman:

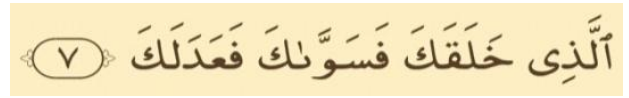

"Yang telah menciptakan kamu lalu menyempurnakan kejadian kamu dan menjadikan (susunan) tubuhmu seimbang” (Q.S. Al-Infithaar:7).

Contoh nilai intelektual yang terkandung dalam pembelajaran biologi pada konsep sistem sirkulasi pada manusia menurut Depriya \& Wulan (2002: 14-15) antara lain: Pengetahuan tentang penyumbatan arteri koronaria jantung oleh kadar kolesterol darah yang tinggi, mengajarkan kepada manusia untuk mampu memilih makanan yang sehat dengan kolesterol rendah; Dengan mengetahui bahwa sirkulasi pada manusia hanya dapat berjalan lancar, teratur, dan seimbang apabila jantung memiliki tekanan tertentu. Tekanan darah normal pada manusia untuk sistol dan diastol adalah 120/80 $\mathrm{mmHg}$. Pengetahuan ini bermanfaat pada manusia untuk senantiasa menjaga tekanan darahnya agar senantiasa normal dengan cara menjaga kualitas hidup.

Contoh nilai praktis pada pembelajaran konsep sistem per-edaran darah menurut Depriya \& Wulan Depriya \& Ratnawulan (2002: 14-15) adalah pemeriksaan frekuensi nadi. Oleh karena frekuensi nadi sama dengan frekuensi denyut jan-tung, maka pemeriksaan denyut jantung dapat dilakukan dengan me-raba arteri radialis pada pergelangan tangan.

Contoh nilai pendidikan yang dapat dikembangkan pada pem-belajaran biologi menurut Depriya \& Wulan Depriya \& Ratnawulan (2002: 14-15) adalah pemahaman sistem transportasi pada manusia dapat diterapkan pada sistem lalu lintas jalan raya yang searah sebagai sistem perlalulintasan yang lebih lancar bila dibandingkan dengan jalur dua arah; Jantung yang 
berdilatasi dan ber-kontraksi dalam menerima dan memompa darah ke seluruh tubuh dapat diterapkan dalam pembuatan sistem irigasi.

Contoh nilai kultural atau kehidupan sosial yang dapat dikaji dalam konsep sirkulasi pada manusia menurut Depriya \& Wulan (2002: 14-15): Kerjasama antar organ pada sistem sirkulasi yang saling men-dukung dalam menjalankan fungsi sirkulasi merupakan per-wujudan gotong royong dari berbagai lapisan masyarakat dalam mencapai tujuan sosial dan budaya.

Contoh nilai yuridis formal yang dapat dikaji dalam konsep sirkulasi pada manusia menurut Depriya \& Wulan (2002: 14-15): Adanya sel-sel darah putih (leukosit) yang berfungsi mempertahankan kesehatan tubuh dengan cara menye-rang antigen serta mikroba yang masuk, mengajarkan kepada suatu sistem masyarakat (negara, kota, desa, dll) untuk membuat sistem keamanan (TNI, Polri, Hansip, Satpam, dll) dalam upaya menjaga keamanan dari berbagai gangguan yang dapat menyebabkan kekacauan.

Semua materi sains pada pembelajaran sains kelas VIII semes-ter II di SMP Pesantren Pramuka Alhira memiliki potensi konflik dan memiliki nilai-nilai toleransi. Materi yang memiliki tingkat kerawanan tinggi untuk terjadi konflik adalah materi sistem peredaran darah manusia karena materi sistem per-edaran darah berhubungan dengan manusia dan berhubungan dangan kehidupan sehari-hari serta ber-hubungan dengan pribadinya.

Contoh konflik yang terjadi pada materi sistem peredaran darah ini adalah ketika guru sains bertanya apakah semua siswa sudah men-getahui golongan darahnya masing-masing? Dari pertanyaan tersebut timbulnya persaingan dan saling meremehkan karakteristik golongan darah dengan mitos-mitos yang beredar dimasyarakat seperti golong-an darah $\mathrm{O}$ itu tidak mudah terserang penyakit sedangkan golongan darah $\mathrm{AB}$ mudah terserang penyakit, guru sains dengan tegas menenangkan siswa, sebelum siswa diberikan pengarahan guru sains meminta pendapat siswa yang lain tentang permasalahan tersebut, setelah para siswa mengajukan pendapatnya, selanjutnya guru sains, memberikan penjelasan tentang permasalahan tersebut, bahwasanya walaupun go-longan darah kita berbeda-beda tetapi dalam kehidupan sehari-hari kita saling membutuhkan, semua manusia memiliki kelebihan dan kekurangan, jika kita mempunyai kelebihan kita hendaknya bersyukur dan membantu teman yang dalam kesusahan, jika kita mempunyai kekurangan kita harus tetap giat dalam belajar dan jangan mudah putus asa. Dalam peristiwa ini, siswa ditanamkan nilai-nilai karakter yang di dalamnya memuat nilai toleransi yaitu, agar siswa dapat menerima dan menghargai teman yang berbeda pendapat, dapat menerima kekurang orang lain, dan terbuka terhadap atau kesediaan untuk menerima sesuatu yang baru.

Contoh lain ketika siswa berebut menjawab petanyaan yang diberikan oleh guru sains, guru sains pun langsung menenangkan siswa, selanjutnya guru sains menunjuk siswa yang tercepat mengacungkan tangan untuk menjawab pertanyaan yang diberikan, jika jawaban yang diberikan belum sempurna, guru sains memberikan kesempatan kepada siswa yang lain untuk menjawab pertanyaan. (hasil wawan-cara) Siswa juga ditanamkan nilai-nilai yang di dalamnya memuat nilai toleransi yaitu, agar siswa tidak memaksakan pendapat diri pada orang lain, bersedia untuk belajar terbuka terhadap gagasan orang lain agar dapat memahami orang lain lebih baik, menerima kesepakatan meskipun berbeda pendapat dengan pendapatnya dan memaafkan kesalahan orang lain. Dari contoh diatas dapat disimpulkan bahwa guru sains kelas VIII SMP Pesantren Pramuka Alhira ikut menanamkan nilai-nilai toleransi kepada siswa-siswi SMP Pesantren Pramuka Alhira.

\section{c. Metode dalam Pembelajaran}


Metode yang sering digunakan guru sains dalam pembelajaran sains terdapat tiga metode, yaitu metode ceramah, metode tanya jawab dan metode diskusi. Metode-metode tersebut dilakukan pada setiap per-temuan, pertama dengan metode tanya jawab yaitu melakukan apersepsi. Pada metode ini siswa dapat belajar menghargai temannya, seperti tidak mengejek, mener-tawakan atau mencemoohkan teman ketika salah, tidak mampu atau belum sempurna dalam menjawab pertanyaan yang diberikan. Kedua dengan metode diskusi, yaitu dengan meminta siswa untuk duduk dalam kelompok, dan memberikan lembar kerja siswa serta membimbing siswa dalam menyelesaikan jawaban, se-lanjutnya mendekati siswa yang menemukan kesulitan dalam diskusi. Memberikan perhatian dan arahan siswa yang kurang melibatkan diri dalam diskusi.

Memberikan kesempatan ke-pada kelompok untuk mempre-sentasikan hasil penemuan mereka didepan kelas dan memfasilitasi diskusi kelas. Ketiga yaitu dengan metode ceramah, yaitu memberi penekanan pada pokok-pokok materi dan memberi penegasan pada jawaban siswa baik yang telah sempurna dalam menjawab maupun yang belum sempurna dalam men-jawab pertanyaan yang diberikan. Metode ceramah ini dilengkapi dengan bantuan powerpoint.

\section{d. Media Pembelajaran}

Media adalah segala sesuatu yang dapat menyalurkan pesan, yang dapat merangsang pikiran, perasaan, dan kemauan siswa sehingga men-dorong terjadinya proses belajar pada dirinya. (Rustaman, 2003: 135) Media yang digunakan guru sains kelas VIII SMP Pesantren Pramuka Alhira Padang Panjang adalah Powerpoint dan Lembar Kerja Siswa (LKS). Media powerpoint ini dapat merangsang pemikiran siswa untuk lebih aktif dan lebih fokus dalam belajar, serta juga meningkatkan rasa keingintahuan siswa, karena tampil-an powerpoint didukung oleh gambar-gambar yang terkait dengan materi pembelajaran, sehingga be-lajar sains lebih bermakna dan menyenangkan. LKS dipilih agar siswa lebih aktif dan kreatif serta tidak selalu bergantung kepada guru. LKS ini dikerjakan secara mandiri dan berkelompok dengan bimbingan atau arahan oleh guru sains, dengan begitu siswa dapat saling bekerja sama dengan anggota kelompoknya, saling menghargai dan menghormati gagasan atau pendapat yang berbeda yang berasal dari dalam kelompok atau kelompok lain pada saat tanya jawab antar kelompok setelah kelom-pok yang terpilih untuk mem-presentasikan hasil kelompoknya.

\section{e. Respon Siswa}

Peserta didik di SMP Pesantren Pramuka Alhira mereka memiliki latar belakang suku, budaya dan bahasa yang berbeda. Dengan adanya keberagaman suku, budaya, dan ba-hasa yang berbeda pada setiap siswa di SMP Pesantren Pramuka Alhira, maka pembelajaran di SMP Pesantren Pramuka Alhira dituntut untuk selalu memahami kondisi kebe-ragaman peserta didik. Dengan selalu menanamkan sikap toleran dan saling menghargai, menghormati ser-ta bekerja sama antar siswa tanpa membedakan suku, budaya dan bahasa.

\section{f. Evaluasi dalam Pembelajaran}

Setiap proses pembelajaran, keberhasilannya diukur dari seberapa jauh hasil belajar yang dicapai, selain diukur dari segi prosesnya. Penca-paian perkembangan siswa perlu diukur, baik posisi siswa sebagai individu maupun posisi siswa dalam kegiatan kelompok. Evaluasi per-sonal sosial memiliki manfaat yang besar bagi seorang guru, khususnya untuk mengetahui secara intensif tingkat adaptasi para siswa. 
Menurut Amri (2014: 20) Fungsi evaluasi dalam proses belajar mengajar, yaitu sebagai berikut:

1) Sebagai alat guna mengetahui apakah peserta didik telah mengetahui pengetahuan, nilai-nilai, dan keterampilan yang telah diberikan oleh seorang guru.

2) Untuk mengetahui aspek-aspek kelemahan peserta didik dalam melakukan kegiatan belajar.

3) Mengetahui tingkat ketercapaian siswa dalam kegiatan belajar.

4) Sebagai sarana umpan balik bagi seorang guru, yang ber-sumber dari siswa.

5) Sebagai alat untuk mengetahui perkembangan belajar siswa.

6) Sebagai materi utama laporan hasil belajar kepada para orang tua siswa.

Evaluasi yang digunakan guru sains kelas VIII SMP Pesantren Pramuka Alhira adalah dengan menggunaka tes lisan, tes tulisan serta untuk penilaian sikap khusus-nya toleransi dilakukan dengan cara penilaian pada saat diskusi, kerja kelompok dan pada saat praktikum.

2. Faktor Pendukung dan Peng-hambat Proses Penanaman Nilai-nilai Toleransi pada Pembelajaran Sains di SMP Pesan-tren Pramuka Alhira Padang Panjang

Untuk mendukung keber-hasilan dalam penanaman nilai-nilai toleransi pada pembelajaran sains di SMP Pesantren Pramuka Alhira Pa-dang Panjang ada faktor pendukung dan penghambat.

a. Faktor Pendukung Penanaman nilai toleransi pada pembelajar-an sains di SMP Pesantren Pra-muka Alhira Padang Panjang

1) Kebijakan peraturan pemerin-tah Nomor 17 Tahun 2010 tentang pengelolaan dan penyelenggaraan pendidikan ber-tujuan membangun landasan bagi berkembangnya potensi peserta didik agar menjadi ma-nusia yang:

a. Beriman dan bertakwa ke-pada Tuhan Yang Maha Esa, berakhlak mulia, dan berkepribadian luhur;

b. Berilmu, cakap, kritis, kre-atif, dan inovatif;

c. Sehat, mandiri, dan percaya diri; dan

d. Toleran, peka sosial, demo-kratis, dan bertanggung ja-wab.

2) Kemampuan guru dalam internalisasi nilai-nilai yang terdapat dalam pembelajran sains, khususnya nilai toleransi dengan cara membangun sikap saling percaya, saling meng-hargai, saling pengertian antar sesama siswa

3) Suasana sekolah yang kondusif untuk penanaman nilai-nilai toleransi

4) Kegiatan-kegiatan pendukung dari pihak sekolah juga sangat berperan penting dalam proses penanaman nilai toleransi, seperti:

a) Kegiatan keagamaan (Ta'li-mul Qur'an, Sholat berja-maah baik sholat fardu dan sholat sunah, membaca Al-qur'an setiap selesai sholat)

b) Kegiatan Kepramukaan (lin-tas alam, lomba pionering, morse dan kepramukaan yang lain)

c) Kegiatan sosial lainnya se-perti kegiatan olah raga, muhadharah atau Public Speaking.

\section{b. Faktor Penghambat Pena-naman nilai toleransi pada pem-belajaran sains di SMP Pesan-} tren Pramuka Alhira Padang Panjang

1) Tingkat kemampuan dan ting-kat kecerdasan yang berbeda-beda yang berada pada satu kelas.

2) Tingkat kematangan emosional siswa yang tidak sama. Hal ini diketahui dari hasil wawancara dengan salah satu pihak seko-lah yaitu, masih adanya siswa yang iri melihat temannya mendapat 
kiriman paket ma-kanan dari keluarga, dan teman tersebut tidak mau berbagi dengan teman yang lain. hal tersebut terjadi karena tingkat kematangan emosional siswa yang tidak sama.

3) Kurangnya fasilitas pada ruangan laboratorium pada saat praktikum yang dapat menun-jang penanaman nilai-nilai toleransi.

Uuntuk mengatasi kendala di atas upaya yang harus dilakukan yaitu:

1) Pemilihan serta mengaplikasi-kan media, sumber belajar dan metode pembelajaran yang menyesuaikan dengan kemam-puan siswa.

2) Guru beserta pihak sekolah harus lebih memahami tingkat pemahaman emosional siswa dengan selalu memberi moti-vasi agar semua siswa tetap bersemangat dan mempunyai sikap toleransi.

3) Sekolah harus lebih memfasi-litasi ala-alat dan bahan untuk melakukan praktikum pada pembelajaran sains.

Sesuai dengan masalah pene-litian diatas, ada ditemukan hasil penelitian yang relevan, yaitu pene-litian yang dilakukan oleh Lina Riqotul Wafiyah dari Institut Agama Islam Negeri Walisongo Semarang Pada penelitian ini fokus pada pena-naman nilai-nilai toleransi beragama pada pembelajaran Pendidikan Aga-ma Islam (PAI). Persamaannya ada-lah Sama-sama membahas toleransi pada siswa sekolah menengah pertama (SMP), teknik analisis data yang digunakan juga sama yaitu analisis data model Miles and Huberman. Sedangkan perbedaannya yaitu penanaman nilai toleransi yang diteliti adalah penanaman nilai-nilai toleransi beragama pada pembelajar-an PAI.

Selain itu, terdapat juga pene-litian yang relevan yaitu penelitian yang dilakukan oleh Busri Endang dosen Jurusan Ilmu Pendidikan FKIP-UNTAN Pontianak. Persama-an penelitian ini sama-sama mem-bahas tentang sikap toleransi dikalangan siswa sedangkan per-bedaannya adalah penelitian yang dilakukan oleh Busri Endang bertujuan untuk mendeskripsikan pentingya pengembangan sikap toleransi dan kebersamaan melalui rekayasa paedagogis guru dalam latar masyarakat majemuk.

\section{Kesimpulan}

Berdasarkan deskripsi yang telah diuraikan di atas maka dapat disimpulkan sebagai berikut: Semua materi sains pada pem-belajaran sains kelas VIII se-mester II di SMP Pesantren Pramuka Alhira Padang Panjang memiliki potensi konflik dan memiliki nilai-nilai toleransi. Ma-teri yang memiliki tingkat kera-wanan tinggi untuk terjadi konflik adalah materi sistem peredaran darah manusia karena materi sistem peredaran darah ber-hubungan dengan manusia dan berhubungan dangan kehidupan sehari-hari serta berhubungan dengan pribadinya.

Penanaman nilai-nilai toleransi pada pembelajaran sains kelas VIII semester II di SMP Pesantren Pramuka Alhira Padang Panjang tergolong baik, dimana pelaksana-an pembelajaran dilakukan den-gan menciptakan iklim toleran pada setiap pembelajaran sains, belajar dalam perbedaan (seperti perbedaan konsep dalam pem-belajaran sains) serta memelihara sikap saling pengertian, saling menghargai dan saling meng-hormati agar siswa dapat mene-rima dan menghargai teman yang berbeda pendapat, dapat mene-rima kekurang orang lain, dan terbuka terhadap atau kesediaan untuk menerima sesuatu yang baru dan agar siswa tidak memak-sakan pendapat diri pada orang lain, bersedia untuk belajar terbuka terhadap gagasan orang lain agar dapat memahami orang lain lebih baik, menerima kese-pakatan meskipun berbeda pen-dapat dengan pendapatnya dan memaafkan kesalahan orang lain.

Ada beberapa faktor pendukung dan penghambat penanaman nilai-nilai toleransi pada pembelajaran sains kelas VIII semester II di SMP Pesantren Pramuka Alhira Padang Panjang, 
faktor pendu-kung diantaranya: Kebijakan Peraturan pemerintah Nomor 17 Tahun 2010 tentang pengelolaan dan penyelenggaraan pendidikan, kemampuan guru dalam internali-sasi nilai toleransi, kegiatan-kegiatan pendukung dari pihak sekolah yang juga sangat ber-peran penting dalam proses penanaman nilai toleransi seperti kegiatan keaga-maan, kegiatan kepramukaan dan kegiatan sosial. Adapaun faktor penghambat diantaranya: Tingkat kemampuan dan tingkat kecerdasan yang berbeda-beda yang berada pada satu kelas. Kematangan emosional siswa yang tidak sama serta kurangnya fasilitas pada ruangan laboratorium pada saat praktikum yang dapat menunjang penanaman nilai-nilai toleransi.

\section{DAFTAR PUSTAKA}

Amri, Sofan. 2013. Pengembangan dan Model Pembelajaran dalam Kurikulum 2013. Jakarta: Prestasi Pustaka.

Arifudin, Iis. 2007. Urgensi Implementasi Pendidikan Multikultural di Sekolah, Vol. 12, No. 2, Mei-Ags 2007. Tersedia dalam http://dow-nload.portalgaruda.org/article. Diakses [7 Maret 2015].

Depriya, M. \& Wulan, A.R. 2002. Pendidikan Nilai pada pembelajaran biologi. Bu-letin PWKG Diknas.

Endang, Busri. Mengembangkan Sikap Toleransi dan Keber-samaan di Kalangan Siswa (Jurnal Visi Ilmu Pendi-dikan). Tersedia dalam http://jurnal.untan.ac.id/index. Diakses [12 Oktober 2014]

Hasil wawancara dengan Utadzah Reni (Guru Sains SMP Alhira) tanggal 18 April 2015.

Kementrian Pendidikan dan Kebudayaan. 2014. Materi Pelatihan Guru Implementasi Kurikulum 2013 tahun 2014. Jakarta: Kementrian Pendi-dikan dan Kebudayaan.

Prudente, M.S. dan Aguja, E.S. 2003. Science Teaching and Learning Process in Pre-service Teacher Educa-tion: The De Salle University-Manila Experience. Elec-tronic Journal of Science Education, Vol 1.

Rustaman, N. dan Rustaman, A. (1997). Pokok-pokok Peng-ajaran Biologi dan Kuri-kulum 1994. Jakarta: Dep-dikbud.

Rustaman, Nuryani Y., dkk. 2003. Strategi Belajar Mengajar Biologi. Bandung: UPI.

Sugiyono. 2012. Memahami Pene-litian Kualitatif. Bandung: Alfabeta.

Yudianto, S.A. 2001. Buku Materi Pokok Biologi Umum Ber-nuansa IMTAK. Bandung: BEP Kanwil DEPAG-IAIN Sunan Gunung Djati. 